\title{
Ectoparasite insects of bats from the fields and weedlands eco-region of Argentina
}

\author{
Analía Gladys Autino ${ }^{1,2,4}$; Fabricio Miguel Idoeta ${ }^{2,5}$; Guillermo Luis Claps ${ }^{3,6}$ \& \\ Rubén Marcos Barquez ${ }^{1,2,7}$
}

${ }^{1}$ Universidad Nacional de Tucumán (UNT), Facultad de Ciencias Naturales e Instituto Miguel Lillo,

Programa de Investigaciones de Biodiversidad Argentina (PIDBA). San Miguel de Tucumán, Tucumán, Argentina.

2 Programa de Conservación de los Murciélagos de Argentina (PCMA). Tucumán, Argentina.

${ }^{3}$ Universidad Nacional de Tucumán (UNT), Facultad de Ciencias Naturales e Instituto Miguel Lillo, Instituto Superior de Entomologia "Dr. Abraham Willink" (INSUE). San Miguel de Tucumán, Tucumán, Argentina.

${ }^{4}$ ORCID: http://orcid.org/0000-0003-2117-0378. E-mail:agautino@yahoo.com.ar

${ }^{5}$ ORCID: http://orcid.org/0000-0002-6450-4449. E-mail: fabricioidoeta@hotmail.com

${ }^{6}$ ORCID: http://orcid.org/0000-0003-0358-0031. E-mail: guillermolclaps@csnat.unt.edu.ar

7 ORCID: http://orcid.org/0000-0002-7027-4950.E-mail: rubenbarquez@gmail.com

\begin{abstract}
New information is presented for bats and their ectoparasite insects from the Argentine Field and Weedlands Ecoregion. Bats of the families Molossidae, Phyllostomidae and Vespertilionidae containing ectoparasites belonging to families Polyctenidae (Hemiptera), Nycteribiidae and Streblidae (Diptera) were collected. Here is presented the first record of Hesperoctenes cartus Jordan, 1922 for Argentina. Basilia plaumanni Scott, 1940 and H. vicinus Jordan, 1922 are added to the province of Misiones and Paratrichobius longicrus (Miranda Ribeiro, 1907) is added to the province of Corrientes. Additionally, the distributions of some ectoparasite insects are extended and new host-ectoparasite associations are reported.
\end{abstract}

Key-Words. Corrientes; Misiones; Nycteribiidae; Polyctenidae; Streblidae.

\section{INTRODUCTION}

In Argentina, most of the studies about bat ectoparasites have been carried out in the northwest region (Autino et al., 1999, 2005, 2009, 2014, 2016; Claps \& Autino, 2012; Lareschi et al., 2016) and in some localities of the northeast of the country (Autino et al., 1998, 2000a, b, 2018; Claps et al., 2004; Oscherov et al., 2006, 2012; Claps \& Autino, 2012; Di Benedetto et al., 2017). Although the Fields and Weedlands ecoregion (located in northeastern Argentina, covering part of the provinces of Corrientes and Misiones) hosts 38 species of bats (Idoeta, 2017), the information about their ectoparasite insects is almost unknown. Taking advantage of a study of bats in the region, we collected and studied their ectoparasite insects. This allowed us to update the species information for some obligate-hematophagous ectoparasite species of the families Nycteribiidae, Streblidae (Diptera) and Polyctenidae (Hemiptera), and present the first available information on the subject for this ecoregion.

\section{MATERIAL AND METHODS}

\section{Study area}

The field research was between 2008-2011 in the Fields and Weedlands ecoregion (Figs. 1, 2), located in the southwest of Misiones and northeast of Corrientes provinces (Matteucci, 2012). The ecoregion is characterized by the presence of subtropical grasses intermingled with mixed and riparian forests, hygrophilous forests, mogotes, savannahs and lagoons, giving rise to a wide ecotone.

In the northern part, the vegetation is made up of grasslands and diverse herbaceous communities, differentiated according to location, whether on hills, slopes or bases of depressions. Because of their subtropical, humid conditions, these grasslands present a great richness in species of grasses and other herbs. There are also gallery forests bordering the rivers and islets, locally known as capones or mogotes. To the south, the plant physiognomy is formed almost purely 


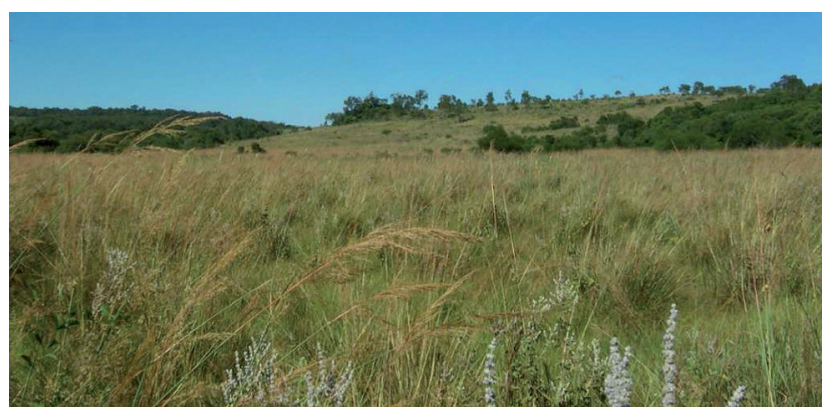

Figure 1. Typical physiognomy of the Fields and Weedlands ecoregion, where the undulating geomorphology of the land is clearly visible, with a predominance of grasses and the presence of "islands" of forests ("mogotes").

by very uniform grasslands known as "Weedlands", located on flood planes that retain moisture for long periods due to the poor drainage (Martínez-Crovetto, 1963; Burkart et al., 1999; Bilenca \& Miñarro, 2004; Di Giacomo \& Krapovickas, 2005; Brown et al., 2006).

\section{Material collection and identification}

The bats were captured with mist-nets placed in several locations (Fig. 2) and identified following Barquez \& Díaz (2009) and Díaz et al. (2011). Voucher specimens were collected and deposited in the Colección Mamíferos Lillo (CML), Universidad Nacional de Tucumán, and in the Colección de Mastozoología del Museo de La Plata (Facultad de Ciencias Naturales y Museo, Universidad Nacional de La Plata, Buenos Aires). Specimens not yet entered in collections are here identified with the initials of the collector's name (FMI) (Fabricio M. Idoeta) followed by his field number.

The ectoparasites were preserved in $70 \%$ alcohol for later identification in the laboratory and deposited at the "CML Annexes Section", identified with the abbreviation CMLA (Colección Mamíferos Lillo Anexos). For some males, the complete specimen and its genitalia were prepared following standard techniques (Graciolli \& Carvalho, 2001) that allow them to be studied under an optical microscope. The ectoparasites were identified using the keys by Guimarães \& D'Andretta (1956); Ronderos (1962a, b; Wenzel et al. (1966); Theodor (1967); Ueshima (1972); Wenzel (1976); Guerrero (1995); Autino et al. (1999); Graciolli \& Carvalho (2001); Graciolli (2004). All parasite and bat specimens were collected by Fabricio M. Idoeta.

The fieldwork was carried out with the help of grants from the CONICET (National Council of Scientific and Technical Research of Argentina) and Conservation Research and Education Opportunities. Collecting permits were issued by the Ministry of Ecology of the province of Misiones, Argentina, granted to Fabricio M. Idoeta.

We offer detailed information for all the species analyzed; the first scientific name of the original description, its author and the year of publication are given, followed by its current name, authors and year of publication. In Material examined, the province, specific locality and geographic coordinates are given, followed by the

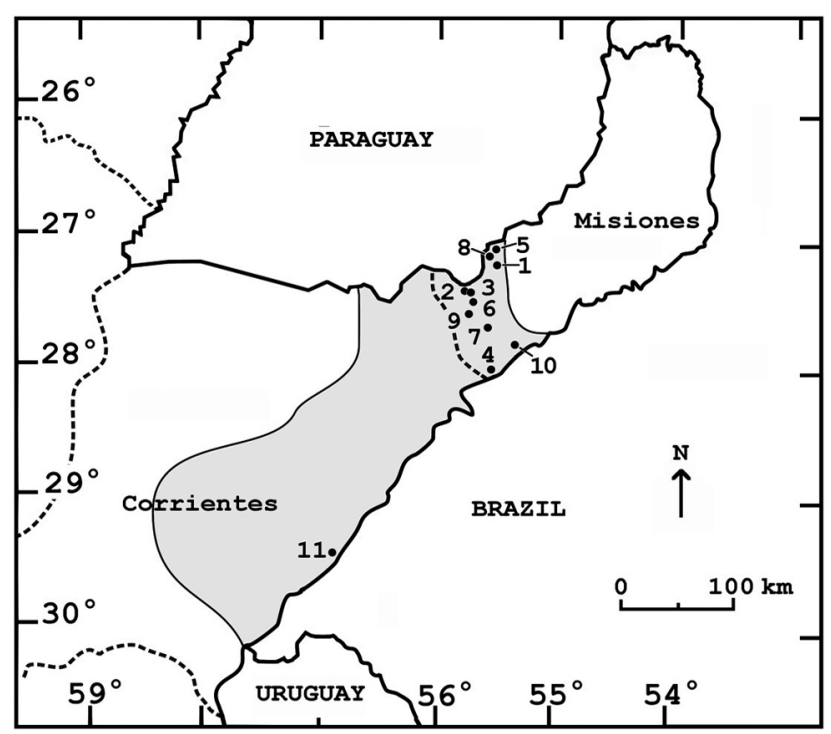

Figure 2. Map of localities mentioned in text. The shaded area indicates the distribution of the Field and Weedlands Eco-region in the argentine provinces of Misiones and Corrientes. Localities were ordered alphabetically and correlatively numbered. Following the number, we offer the name of the specific locality, geographic coordinates and Province and Provincial Department, both in parenthesis. (1) Camping Japonés, Arroyo Yabebiry, Loreto (27 $17^{\prime} S$, $\left.55^{\circ} 30^{\prime} \mathrm{W}\right)$ (Misiones, Candelaria); (2) Candelaria (Misiones, Candelaria) $\left(27^{\circ} 28^{\prime} \mathrm{S}, 55^{\circ} 45^{\prime} \mathrm{W}\right)$; (3) Candelaria, Balneario Arroyo Garupá (Misiones, Candelaria) $\left(27^{\circ} 29^{\prime} \mathrm{S}, 55^{\circ} 44^{\prime} \mathrm{W}\right)$; (4) Estancia Prates, Barra Concepción

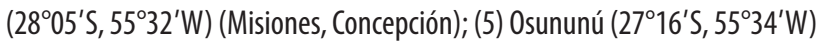
(Misiones, San Ignacio); (6) Parque Provincial Cañadón de Profundidad $\left(27^{\circ} 33^{\prime} \mathrm{S}, 55^{\circ} 42^{\prime} \mathrm{W}\right)$ (Misiones, Candelaria); (7) Parque Provincial de la Sierra "Ingeniero Agrónomo Martínez-Crovetto", Municipio de San José, $210 \mathrm{~m}$

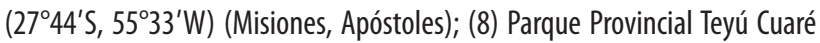
(27ำ $\left.17^{\prime} \mathrm{S}, 55^{\circ} 35^{\prime} \mathrm{W}\right)$ (Misiones, San Ignacio); (9) Reserva Ecológica Tupá

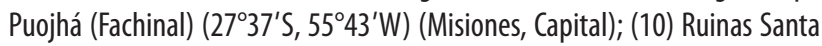
María (27 $\left.53^{\prime} \mathrm{S}, 55^{\circ} 20^{\prime} \mathrm{W}\right)$ (Misiones, Concepción de la Sierra); (1) Yapeyú $\left(29^{\circ} 28^{\prime} \mathrm{S}, 56^{\circ} 49^{\prime} \mathrm{W}\right)$ (Corrientes, General San Martín).

number of specimens examined, their sex and, in parentheses, the number of the Collection where they are deposited. The species of host bats on which they were found, sex and collection numbers are also indicated. A Comments section is also included, primarily detailing information related to the distribution or taxonomy of the species. We only include photographs of Hesperoctenes cartus because it is a species with no previous records in Argentina.

\section{RESULTS}

A total of 10 species of bats were captured, four belonging to the Family Phyllostomidae: Artibeus fimbriatus Gray, 1838, A. lituratus (Olfers, 1818), Carollia perspicillata (Linnaeus, 1758) and Sturnira lilium (É. Geoffroy St.-Hilaire, 1810), four Molossidae: Cynomops abrassus (Temminck, 1826), C. planirostris (Peters, 1865), Eumops patagonicus Thomas, 1924 and Molossops temminckii (Burmeister, 1854) and two Vespertilionidae: Eptesicus furinalis (d'Orbigny \& Gervais, 1847) and Myotis izecksohni Moratelli, Peracchi, Dias \& de Oliveira, 2011. 
Ectoparasite insects collected included six Diptera (Family Streblidae): Megistopoda aranea (Coquillett, 1899), M. proxima (Séguy, 1926), Metelasmus pseudopterus Coquillett, 1907, Paratrichobius longicrus (Miranda Ribeiro, 1907), Strebla guajiro (García \& Casal, 1965) and Trichobius furmani Wenzel, 1966, two Diptera (Family Nycteribiidae): Basilia carteri Scott, 1936 and B. plaumanni Scott, 1940 and two Hemiptera (Family Polyctenidae): Hesperoctenes cartus Jordan, 1922 and H. vicinus Jordan, 1922.

\section{Diptera (Streblidae)}

\section{Megistopoda aranea (Coquillett, 1899)}

Pterellipsis aranea Coquillett, 1899: 334.

Megistopoda aranea: Wenzel et al., 1966: 541-542.

Material examined: Misiones: Estancia Prates, Barra Concepción, $28^{\circ} 05^{\prime} \mathrm{S}, 5^{\circ} 32^{\prime} \mathrm{W}$, 05.iii.2011, 1 \% (CMLA 725) and $10^{\prime \prime}$ (CMLA 726) on Artibeus fimbriatus 9 (FMI 271); 27.iii.2011, 1 ( (CMLA 728) and $1 \sigma^{7}$ (CMLA 727) on A. fimbriatus $\$$ (FMI 285); Parque Provincial Teyú Cuaré, $27^{\circ} 17^{\prime} \mathrm{S}, 55^{\circ} 35^{\prime} \mathrm{W}$, 11.xii.2009, (4) 2 9 (CMLA 732, 733) and 2 ơ $^{\prime}$ (CMLA 730, 731) on A. lituratus 9 (FMI 151); Reserva

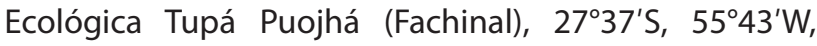
30.iv.2010, 1 \% (CMLA 729), on A. fimbriatus \& (FMI 20).

Identification: This species is easily distinguishable from M. proxima by its long and narrow wings with two veins that unite with the costa; very long legs, including a hind femur nearly as long as the entire body; prescutum with very weak setae along the median suture; and lateral margins along the longitudinal membranous suture that include one or two stronger setae.

Comments: This species had only been previously identified in one locality in Corrientes province (Autino et al., 2009) and several in Misiones, having recently been cited for the Osununú-Teyú Cuaré AICOM (Area of Importance for the Conservation of Bats) (Autino et al., 2018). It has also been cited for some localities in the northwestern Argentina (Jujuy, Salta and Tucumán) (Autino et al., 1999, 2009).

The known host records for Megistopoda aranea are mainly from bats of the family Phyllostomidae, as Artibeus fimbriatus, A. lituratus, A. planirostris (Spix, 1823) and Desmodus rotundus É. Geoffroy, 1810 (García, 1959; Barquez et al., 1991; Autino et al., 1992, 1998, 1999, 2000b, 2009, 2018).

\section{Megistopoda proxima (Séguy, 1926)}

Pterellipsis proxima Séguy, 1926: 194, figs. 1-6. Megistopoda proxima: Wenzel et al., 1966: 543.

Material examined: Misiones: Estancia Prates, Barra Concepción, $28^{\circ} 05^{\prime} \mathrm{S}, 5^{\circ} 32^{\prime} \mathrm{W}$, 26.iii.2011, 1 ơ $^{\prime}$ (CMLA 759) on S. lilium + (FMI 274); Reserva Ecológica Tupá Puojhá
(Fachinal), $27^{\circ} 37^{\prime} \mathrm{S}, 55^{\circ} 43^{\prime} \mathrm{W}$, 03.v.2010, 1 ( (CMLA 749), 2 \% (CMLA 750, 751) on S. lilium $\&$ (FMI 214); Parque Provincial Cañadón de Profundidad, $27^{\circ} 33^{\prime} \mathrm{S}, 55^{\circ} 42^{\prime} \mathrm{W}$, 18.xii.2009, $1 \sigma^{\pi}$ (CMLA 760) on S. lilium o' (FMI 161);

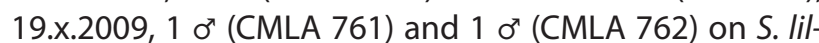
ium o (FMI 170); Parque Provincial Teyú Cuaré, 2717'S,

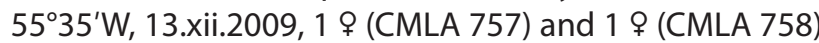
on S. lilium or (FMI 153).

Identification: Some authors consider that Megistopoda proxima is a complex of species. Wenzel (Wenzel et al., 1966) described Megistopoda theodori but later (Wenzel, 1976) he treated it as a junior synonym of M. proxima. However, some authors such as Dick et al. (2007), Dick (2013) and Autino et al. (2018) considered M. proxima and $M$. theodori as different species, although they expressed that the "proxima group" contains several species not yet described. The specimens studied here have wings exactly like those of $M$. proxima but, analyzing the genitalia of the males, they are totally different from that of M. proxima. As differences in the external morphology were also observed, we consider that studied specimens are members of the Megistopoda proxima complex, but that they merit the description of a new species, which is in process.

Comments: This ectoparasite is frequently found on bats of the genus Sturnira throughout its range. In Argentina, it has been cited on Sturnira erythromos (Tschudi, 1844), S. lilium and S. oporaphilum (Tschudi, 1844) from Catamarca, Jujuy, Salta and Tucumán (Barquez et al., 1991; Autino et al., 1992, 1998, 1999, 2000b; Claps et al., 2000) and on S. lilium in Misiones (Autino et al., 2018) but cited as M. theodori.

\section{Metelasmus pseudopterus Coquillett, 1907}

Metelasmus pseudopterus Coquillett, 1907: 292.

Material examined: Misiones: Estancia Prates, Barra Concepción, $28^{\circ} 05^{\prime} \mathrm{S}, 5^{\circ} 32^{\prime} \mathrm{W}, 25 . i i i .2011,1$ 우 (CMLA 717) and $1 \sigma^{\prime \prime}$ (CMLA 718) on Artibeus fimbriatus (FMI 271); 26.iii.2011, 3 ơ (CMLA 711, 712, 713) on A. fimbriatus 9 (FMI 272); Reserva Ecológica Tupá Puojhá

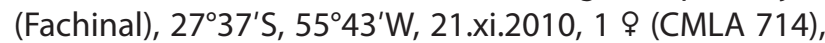
$2 \mathrm{o}^{\top}$ (CMLA 715, 716) on Eptesicus furinalis 9 (FMI 230).

Identification: Metalasmus pseudopterus is easily recognizable by its bell-shaped head with a comb of closely spaced thick spines (ctenidium) along the posterior ventral margins. The ctenidium, consisting of numerous spines, extends dorsoventrally on the posterior margin of the head; broad scales (remiform scale) are present on the side of the head behind the ctenidium; and the wings are brachypterous, almost oval shaped, with only four longitudinal veins. Female: tergite VII with one pair of setae. Male: gonopod shorter; rapidly narrowing toward the hooked apex (Guerrero, 1996; Autino et al., 1999; Graciolli \& Carvalho, 2001). 
Comments: This species parasitizes widely on bats of the family Phyllostomidae, although it has been cited for Emballonuridae on Peropteryx macrotis (Wagner, 1843) and for Vespertilionidae on Myotis nigricans (Schinz, 1821) (Vespertilionidae) (Graciolli \& Carvalho, 2001). In northern Argentina, it has been recorded on Artibeus fimbriatus (Misiones) (Claps et al., 2000; Autino et al., 2009) and A. planirostris (Jujuy, Salta and Tucumán) (Autino et al., 1999, 2009).

\section{Paratrichobius longicrus (Miranda Ribeiro, 1907)}

Trichobius longicrus Miranda Ribeiro, 1907: 236, pl. 25. Paratrichobius longicrus: Costa Lima, 1921: 20, pl. 1.

Material examined: Corrientes: Yapeyú, $29^{\circ} 28^{\prime} S$, 56 48'W, 12.x.2009, 1 \% (CMLA 723) on Eumops patagonicus \& (FMI 135). Misiones: Estancia Prates, Barra Concepción, $28^{\circ} 05^{\prime} \mathrm{S}, 55^{\circ} 32^{\prime} \mathrm{W}$, 23.iii.2011, $10^{\prime \prime}$ (CMLA 719) on Artibeus lituratus o' (FMI 267); Reserva Ecológica Tupá

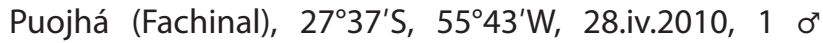
(CMLA 724) on A. lituratus 9 (FMI 200); Camping Japonés, Arroyo Yabebiry, Loreto, $27^{\circ} 17^{\prime} \mathrm{S}, 55^{\circ} 30^{\prime} \mathrm{W}$, 23.xi.2010, $1 \sigma^{7}$ (CMLA 720) on A. lituratus $\sigma^{7}$ (FMI 233); Osununú, $27^{\circ} 16^{\prime} \mathrm{S}, 55^{\circ} 34^{\prime} \mathrm{W}$, 30.xi.2010, $10^{\circ}$ (CMLA 721) sobre $A$. lituratus ㅇ (FMI 251); Ruinas Santa María, $27^{\circ} 53^{\prime} \mathrm{S}, 55^{\circ} 20^{\prime} \mathrm{W}$, 01.iv.2011, $1 \sigma^{\Upsilon}$ (CMLA 722) on A. lituratus 9 (FMI 297).

Identification: This species is easily recognizable by its very long hind legs, in which the femur reaches or exceeds the tip of the wings. Femur I has a complete row of short setae medial and in parallel a row of six stout spines on the inner face; and the hind femur is nearly as long as the thorax and abdomen combined (Graciolli \& Carvalho, 2001).

Comments: This species is parasitic to several bats of the family Phyllostomidae, mainly of the genus Artibeus (Wenzel et al., 1966), although it has also been recorded in Molossidae and Noctilionidae (Graciolli \& Carvalho, 2001). In Argentina, it has only been cited on Artibeus lituratus (Autino et al., 1998, 2000b, 2018). A very remarkable characteristic of this species are their very long hind legs, with femurs that reach, or exceed, the tips of the wings, which are also long.

\section{Strebla guajiro (García \& Casal, 1965)}

Euctenodes guajiro García \& Casal, 1965: 14, figs. 10-16. Strebla guajiro: Wenzel, 1976: 151.

Material examined: Misiones: Parque Provincial Teyú Cuaré, $27^{\circ} 17^{\prime} \mathrm{S}, 55^{\circ} 35^{\prime} \mathrm{W}, 10 . x .2009,1 \sigma^{\prime \prime}$ (CMLA 748) on Carollia perspicillata 9 (FMI 139).

Identification: The genus Strebla contains 26 species (Dick \& Graciolli, 2018) but the one treated in this study differs from all the others as the frontoclypeus have a pair of detached plates or an unsclerotized median suture; the second anterior pigmented mesonotal suture is usually distinct; the tibia III has only two or three distal setae on the dorsal surface that are longer than the others; the preceding setae are less than twice long as the other tibial setae; the prescutum has only two irregular transverse rows of setae laterally between the transverse mesonotal suture and the anterior suture; the postvertex has eight strong macrosetae arising from the posterior margin on each side; the thoracic setae is anterior to the mesonotal suture sparse; and the male genitalia have postgonites at a curved angle (Wenzel et al., 1966; Graciolli \& Carvalho, 2001).

Comments: The main host for this species is C. perspicillata; however, there are also records for other species of Phyllostomidae, and species of other families such as Mormoopidae, Natalidae and Vespertilionidae. In Argentina, it was only found parasitizing Carollia perspicillata from Misiones (San Ignacio Department) (Autino et al., 2018). As in all species of this genus, their legs are short and thick and the hind legs are slightly longer than forelegs.

\section{Trichobius furmani Wenzel, 1966}

Trichobius furmani Wenzel, 1966 in Wenzel et al., 1966: 490, fig. 2A.

Material examined: Misiones: Parque Provincial Teyú Cuaré, $27^{\circ} 17^{\prime} \mathrm{S}, 55^{\circ} 35^{\prime} \mathrm{W}, 10 . x .2009,1$ \% (CMLA 763) on Carollia perspicillata ơ (FMI 148).

Identification: This species belongs to the parasiticus complex, in which the metasternal lobe is absent. It may be easily differentiated from Trichobius dugesioides Wenzel 1966, to which it is related, by the extremely long antescutellar bristles, some of which are three or four times as long as the scutal setae immediately anterior to them (less than twice as long in T. dugesioides); the extensive microsetose area on the prescutum; and the male gonapophyses are long and feebly curved in the lateral view (Wenzel et al., 1966; Graciolli \& Carvalho, 2001).

Comments: This species was recorded in Argentina by Autino et al. (2018). Although the host bat for the type specimen is Desmodus rotundus (Phyllostomidae), it has been also reported on other species of Phyllostomidae, such as Carollia perpicillata, Diphylla ecaudata Spix, 1823 and Glossophaga soricina (Pallas, 1766), and on the Molossidae species Molossus molossus (Pallas, 1766).

\section{Diptera (Nycteribiidae)}

\section{Basilia carteri Scott, 1936}

Basilia carteri Scott, 1936: 498. 
Material examined: Misiones: Parque Provincial de la Sierra "Ingeniero Agrónomo Martínez-Crovetto", Municipio de San José, $27^{\circ} 44^{\prime} 39.49^{\prime \prime}$ S, 55³3'56.40"W, 210 m, 28.iv.2010, 3 \% (CMLA 841, 842, 843), on Myotis izecksohni ơ (CML 10200).

Identification: This species is characterized by the head having 4 setae on the anterior dorsal margin and 12-15 notopleural setae between the eyes. The male abdomen has tergite 2 with a row of short setae on the surface and tergites 3-6 bare; and sternite 4 has a marginal row has long setae. The female abdomen has tergite I broadly rounded posteriorly with a row of 12-16 long setae in the middle and shorter setae on the lateral margins and sides of the surface. The anal segment is broadly conical, with long setae posteriorly and short setae laterally. The pleurae are covered with minute spines.

Comments: The host species Myotis izecksohni was recently described by Moratelli et al. (2011) and recorded in Argentina by Barquez et al. (2017) in the province of Misiones in the locality indicated in material examined. Basilia carteri is recorded in northern Argentina on hosts of the families Vespertilonidae and Molossidae, including reports from Corrientes on M. albescens (É. Geoffroy SaintHilaire, 1806) (Claps et al., 2004); from Chaco on Myotis nigricans (Autino et al., 2009); from Jujuy on Molossops temminckii and M. albescens (Guimarães, 1946; Autino et al., 2009); from Misiones on M. levis (I. Geoffroy SaintHilaire, 1824) (Autino et al., 2009); from Salta on M. albescens and M. riparius Handley, 1960 (Autino et al., 1999); from Santiago del Estero on M. nigricans and Tadarida brasiliensis (I. Geoffroy Saint-Hilaire, 1824) (Guimarães \& D’Andretta 1956; García, 1959); and from Tucumán on Tadarida brasiliensis, M. albescens, M. keaysi Allen, 1914, and M. riparius (Autino et al., 1999, 2000a, 2009).

\section{Basilia plaumanni Scott, 1940}

\section{Basilia plaumanni Scott, 1940: 58.}

Material examined: Misiones: Candelaria, $27^{\circ} 28^{\prime} S$, 55 $5^{\circ} 5^{\prime} \mathrm{W}, 02 . v .2010,2$ (CMLA 786, 787) on Eptesicus furinalis $\$$ (FMI 179), 1 (CMLA 788) and $1 \sigma^{\pi}$ (CMLA 789) on E. furinalis o" (FMI 180); Candelaria, Balneario arroyo

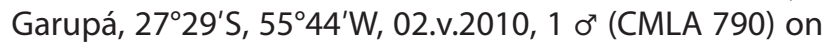
E. furinalis ơ (FMI 181).

Identification: The head of this species is characterized by having four to six setae on the anterior dorsal margin, two setae between the eyes, and eight to ten notopleural setae. Generally, the mesonotum of the females is distinguished by a posterior triangular elevation, although this feature is absent in some specimens. The tergum I of females exhibits a row of short, thin setae on the rounded posterior margin, while the tergal plate II is large and heart-shaped, with broadly rounded posterior processes that bear three long setae and 10-15 short spines. The female continues to be distinguished by a conical anal segment, with one to two longer posterior setae and various short lateral ones. The pleura is covered with minute spines, and the genital plate bears two to four long setae. The anal sclerite is small, with two setae, and is not connected to the genital plate. Basilia plaumanni has the abdomen with the posterior edge of tergite II ending in two lobes with strong setae while $B$. carteri has the tergite II with rounded edges, with long setae interspersed with short setae (Autino et al., 1999, Graciolli \& Carvalho, 2001).

Comments: This ectoparasite has been recorded in Argentina on bats of the family Vespertilionidae. It is has been recorded in Córdoba and Jujuy on Histiotus laephotis Thomas, 1916 (García, 1959; Autino et al., 1999, 2016); in Salta on H. macrotus (Poeppig, 1835) (Autino et al., 2009); and in Corrientes and Santiago del Estero on Eptesicus furinalis (García, 1959; Oscherov et al., 2012). The identity of the specimen cited as $\mathrm{H}$. laephotis from Córdoba is doubtful (Barquez, 2006).

\section{Hemiptera (Polyctenidae)}

\section{Hesperoctenes cartus Jordan, 1922}

Hesperoctenes cartus Jordan, 1922: 211-212.

Material examined: Misiones: Parque Provincial Cañadón de Profundidad, $27^{\circ} 33^{\prime}$ S, 55 $42^{\circ} \mathrm{W}$, 19.x.2009, 2 우 (CMLA 740, 741) on Cynomops planirostris o' (CML 8917); 18.x.2009, 1 \% (CMLA 747), 1 o' (CMLA 770) on Cynomops abrasus + (CML 8910); 18.x.2009, 2 ㅇ (CMLA 737, 738), 3 o' (CMLA 739, 765, 769) on C. abrasus 9 (CML 8911); 18.x.2009, 1 o' (CMLA 735), 1 9 (CMLA 736) on C. abrasus 9 (CML 8912); 18.x.2009, 4 9 (CMLA 742, 743, 773, 744), 2 o' (CMLA 745, 746) on C. abrasus 9 (CML 8915); 18.x.2009, 29 (CMLA 734, 766) on C. abrasus 9 (CML 8913); 19.x.2009, $10^{7}$ (CMLA 772) on C. planirostris 9 (CML 8916); 19.x.2009, $1 \sigma^{7}$ (CMLA 768) on C. planirostris o (CML 8920); 19.x.2009, 1 \% (CMLA 771) on C. planirostris o' (CML 8917); 18.x.2009, 2 ㅇ (CMLA 777, 778), 2 o' (CMLA 775, 776) on 4 released specimens of $C$. abrasus + .

Identification: See Figs. 3 and 4 for photographs of this species. The bristles on the upper side of the head and prothorax are remarkably few in number, with the discolateral patch of the head having twelve to fifteen bristles, the patch before the posterior angle represented by two or three, and the central area bearing less than sixty. The bare spaces on the pronotum occupy a much larger portion of the surface than the setiferous spaces; the naked spaces on the antemedian and posthumeral are merged together; and the posterior third of the surface is almost entirely naked from side to side, except for the marginal bristles. The gular comb consists of seventeen to twenty spines. From the middle to the posterior margin of the head there is an irregular double row of eleven to fourteen bristles, which (as in $\mathrm{H}$. vicinus) are larger than the small bristles that flank the central, longitudinal groove of the gula. The prosternum has a bare area somewhat 


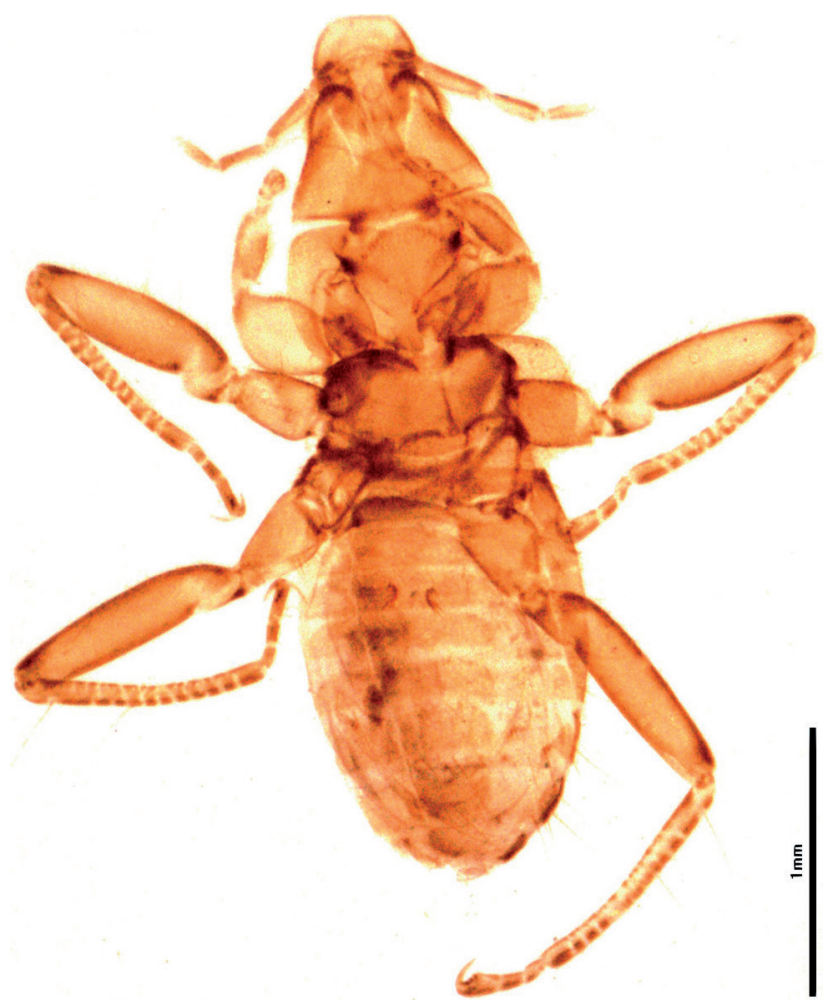

Figure 3. Hesperoctenes cartus (CMLA 766 \%) (dorsal view).

extended in the middle. Elytra and abdomen are as in H. vicinus.

This species resembles Hesperoctenes vicinus; however, the lengths of the antennal segments are different than those in $\mathrm{H}$. vicinus because, in $\mathrm{H}$. cartus, segments III and IV are practically equal in length; whereas, in $\mathrm{H}$. vicinus, the IV is distinctly longer than III and II is almost half as long as III. The legs resemble those of $H$. vicinus (Jordan, 1922; Ronderos, 1962a, b).

Comments: The specimens listed in Material examined represent the first records of this species for Argentina. They have been found on Cynomops planirostris and C. abrasus. This is a widely distributed species and was recorded in Brazil, Colombia, Paraguay, Panamá and Venezuela (Ueshima, 1972; Dick \& Bindokas, 2007). The host type of $\mathrm{H}$. cartus is Nyctinomops laticaudatus laticaudatus (É. Geoffroy, 1805) (cited as Dysopes gracilis J.A. Wagner, 1845) from Santa Catarina, Brasil (Jordan, 1922). It was also included on Cynomops abrasus (Temmink, 1827) (cited as Molossus cerastes Thomas, 1901) from Paraguay (Sapucay) (Ferris \& Usinger, 1939) and Cynomops planirostris (Peters, 1866) (cited as Molossops planirostris [Peters, 1866]) from Venezuela, Panamá and Colombia (Ueshima, 1972).

\section{Hesperoctenes vicinus Jordan, 1922}

Hesperoctenes vicinus Jordan, 1922: 210-211.

Material examined: Misiones: Parque Provincial Cañadón de Profundidad, $27^{\circ} 33^{\prime} \mathrm{S}, 5^{\circ} 42^{\prime} \mathrm{W}$, 03.iii.2010, 1 (CMLA 774) on Molossops temminckii o (FMI 182).
Identification: This species is characterized by patches or rows of bristles on the medial posterior margin of the underside of the head. The gular crest is defined by an irregular double row of six to eight bristles on the middle of the hind margin. Antennal segments I and III are equal in length, and the labrum is proportionally three times wider than long. The bristles located on other parts of the body are sparse and distributed irregularly, including numerous bare areas on the pronotal disk. The species is similar to H. cartus, but has more bristles with the exception of the gular marginal row, which contains fewer bristles than in $\mathrm{H}$. cartus, and the second antennal segment is shorter (Jordan, 1922; Ronderos, 1962a, b).

Comments: This species was previously known only from Paraguay, reported on Molossus rufus (= M. ater; Ueshima, 1972) and from Argentina on Molossops temminckii. Here its distribution in Argentina is extended quite far east, reaching the province of Misiones. Previously, it was known only from Jujuy and Salta on M. temminckii (Autino et al., 2009, 2016).

\section{DISCUSSION}

Up to now, 48 species of bat ectoparasite insects, 28 Diptera (22 Streblidae and six Nycteribiidae), 13 Hemiptera (nine Polyctenidae and four Cimicidae) and seven Siphonaptera, have been cited for Argentina. In this study, we add new information that represents the first survey on bat ectoparasites from the Fields and Weedlands Ecoregion. The most important contributions of this study are the addition of one species to the province of Corrientes (Paratrichobius longicrus), three species to Misiones (Basilia plaumanni, Hesperoctenes cartus and $H$. vicinus) and two new host-ectoparasite associations (Metelasmus pseudopterus with Eptesicus furinalis, and Basilia carteri with Myotis izecksohni), including the firsttime reported association of a species of Nycteribiidae with the recently described bat, Myotis izecksohni. The known distribution for most of the studied species is also extended.

For the family Streblidae, although Megistopoda aranea was already recorded in Misiones (Autino et al., 2018), its distribution is extended to other provincial departments (Capital and Concepción) where it had not been previously registered. Similarly, Megistopoda proxima, already known from Misiones (Séguy, 1926; Autino et al., 1998, 1999, 2000a), is here recorded from the provincial departments of Candelaria, Capital and Concepción; Autino et al. (2018) also recorded this species for Misiones province but miscited it as M. theodori. Metelasmus pseudopterus, previously known from Iguazú Department (Autino et al., 2009), is reported here from the departments Capital and Concepción de la Sierra. Although its main hosts belong to the family Phyllostomidae, it also has been recorded on Vespertilionidae, though with less frequency; here we also reported a new association with Eptesicus furinalis. Paratrichobius longicrus is added to the fauna of Corrientes and, although it had already been recorded in Misiones 
(Autino et al., 1998, 2000b, 2018), here it is recorded in the departments of Concepción, Capital and Candelaria; a new association with $E$. patagonicus is also reported. Strebla guajiro was also collected during this study, but it was already known for Misiones (Autino et al., 2018).

For the family Nycteribiidae, Basilia carteri was reported only from the extreme north of Misiones province (Autino et al., 2009), and its distribution is here extended about $350 \mathrm{Km}$ south from the previously known locality to Puerto Península. In addition, its association with M. izecksohni, a recently described species of bat for which nothing was known with respect to its ectoparasites, is reported for the first time. Although the distribution of Basilia plaumanni is wide in northern Argentina, its distribution in the northeast was known only in Corrientes province, and is here added to the province of Misiones.
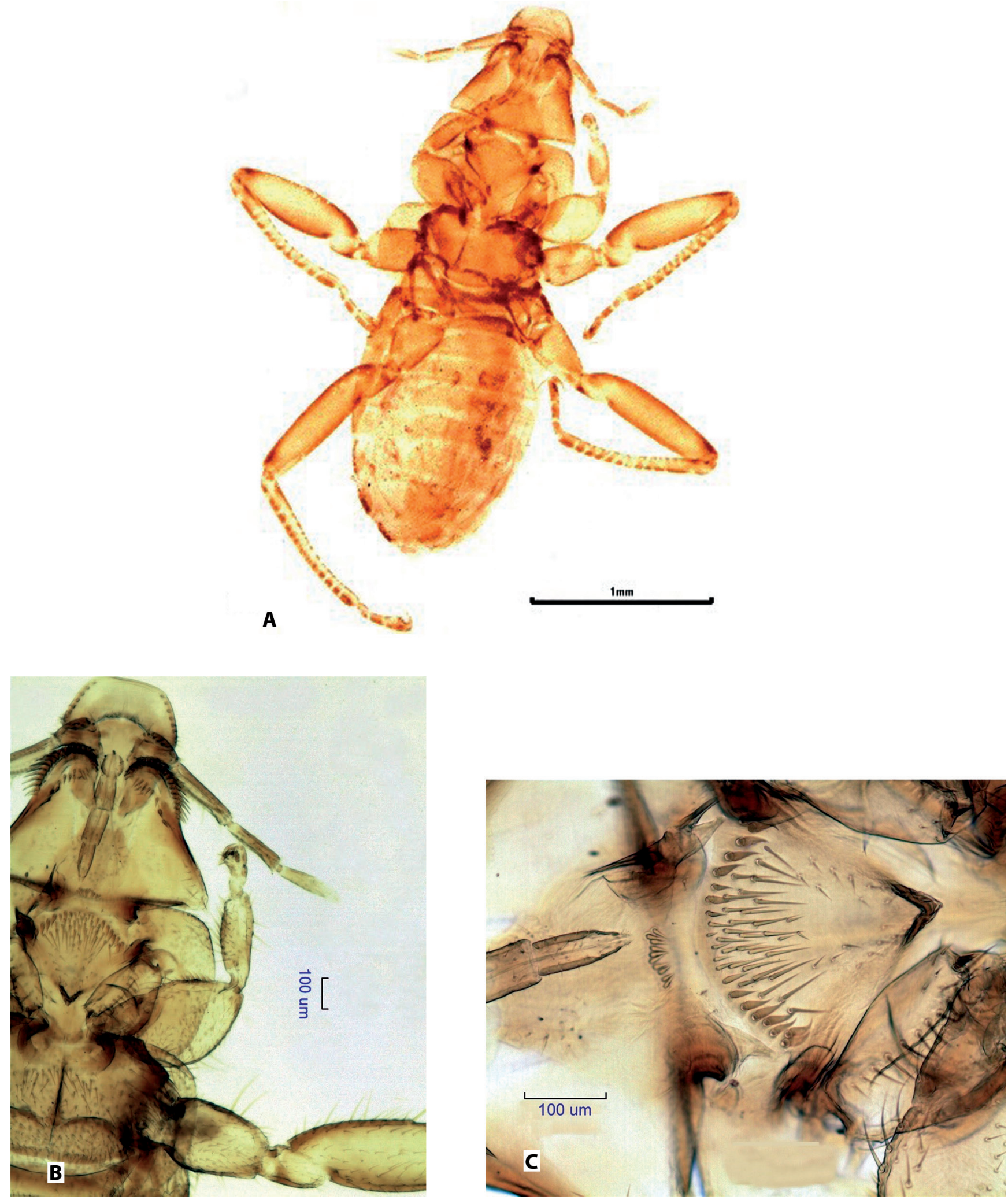

Figure 4. Hesperoctenes cartus (CMLA 766 \%): (A) Ventral view, (B) Antenna and anterior leg, (C) Gular region and Prosternum. 
For the family Polyctenidae, there is no record of the species Hesperoctenes cartus for Argentina. We here reported this species in Argentina through records from Misiones, which represent the southernmost known distribution for this species. With this, the total number of species of Polyctenidae in Argentina rises to ten and the total number of species of ectoparasite insects in the country increases to 49 . Hesperoctenes vicinus has a wide distribution, but only a few records from Paraguay and northwestern Argentina (provinces of Jujuy and Salta) noted hosts of the family Molossidae (Ueshima, 1972; Autino et al., 2009, 2016); here we add a locality to the distribution of this species in Misiones province, northeastern Argentina.

The Field and Weedlands ecoregion have been neglected for study by most researchers, likely because they are more concerned with analyzing the Paraenean Forests and consider the Fields simply as an impoverished subregion. However, the Fields is an area of high biogeographical interest due to its vegetational continuity with countries such as Brazil and Paraguay, which from more tropical latitudes are "providers" of fauna towards the austral gradient (Barquez, 2004). By virtue of its heterogeneous ecosystem that results from the alternation of grasses, mountain islets, savannahs and gallery forests that border the water courses, a great diversity of environments are generated, which is reflected in its chiropterofauna and, therefore, in parasitic insects. The present study, therefore, serves as a basis for future research on the biodiversity of bats and their parasites in the region and surrounding areas.

\section{ACKNOWLEDGMENTS}

To CONICET (National Council of Scientific and Technical Research, Argentina) for the granting of a doctoral scholarship to F.M. Idoeta. To the Ministry of Ecology of the province of Misiones for the collection permits. To "Conservation Research and Education Opportunities" for the financial help for the development of the collection campaigns. To Julieta Pérez and Nicolás Melchert for taking the pictures of Figures 3 and 4. We thank Jennifer Richardson for the grammatical revision of the English.

\section{AUTHORS' CONTRIBUTIONS:}

AGA and GLC identified the ectoparasites; FMI collected the ectoparasites and bats; AGA, GLC and RMB wrote the manuscript; FMI and RMB identified the species of bats; all authors participated in the results discussion and reviewed and approved the final version of the paper.

\section{REFERENCES}

Autino, A.G.; Barquez, R.M. \& Claps, G.L. 1992. Nuevas citas de dípteros ectoparásitos (Streblidae) para murciélagos de la Argentina. Revista de la Sociedad Entomológica Argentina, 50(1-4): 248-260.
Autino, A.G.; Claps, G.L. \& Barquez, R.M. 1999. Insectos ectoparásitos de murciélagos de las Yungas de la Argentina. Acta Zoológica Mexicana (nueva serie), 78: 119-169.

Autino, A.G.; Claps, G.L. \& Barquez, R.M. 2000a. Nuevos registros de Diptera y Siphonaptera en la Argentina. Boletin de Entomologia Venezolana, 15(1): 109-112.

Autino, A.G.; Claps, G.L. \& del Castillo, A.F. 2000b. Aportes a la reproducción y ectoparásitos (Diptera: Streblidae) de murciélagos (Mammalia: Chiroptera) del Parque Nacional Iguazú, Misiones, Argentina. Neotrópica, Argentina, 46: 71-73.

Autino, A.G.; Claps, G.L. \& Barquez, R.M. 2014. El género Aspidoptera Coquillett (Diptera, Streblidae) en la Argentina. Revista de la Sociedad Entomológica Argentina, 73(1-2): 75-79.

Autino, A.G.; Claps, G.L. \& Bertolini, M.P. 1998. Primeros registros de insectos ectoparásitos de murciélagos del Parque Nacional Iguazú, Misiones, Argentina. Revista Brasileira de Entomologia, 42(1-2): 59-63.

Autino, A.G.; Claps, G.L. \& Ortiz, F. 2005. Primera cita de Sternopsylla distincta speciosa (Siphonaptera: Ischnopsyllidae) para la provincia de Jujuy, Argentina. Revista de la Sociedad Entomológica Argentina, 64(1-2):34-36.

Autino, A.G.; Claps, G.L.; Sanchez, M.S. \& Barquez, R.M. 2009. New records of bat ectoparasites (Diptera, Hemiptera and Siphonaptera) from northern Argentina. Neotropical Entomology, 38(2): 165-177.

Autino, A.G.; Di Benedetto, I.M.D.; Palmerio, A. \& Claps, G.L. 2018. Streblidae (Diptera) ectoparásitos de murciélagos del AICOM Osununú/Teyú Cuaré, San Ignacio, Misiones, con la primera cita de Trichobius furmani en Argentina. Revista de la Sociedad Entomológica Argentina, 77(3): 30-35.

Autino, A.G.; Ortiz, F.; Claps, G.L. \& Bracamonte, J.C. 2016. New host and locality records for chiropteran ectoparasites from Jujuy and Salta provinces, Argentina. Check List, 12(3): 1895.

Barquez, R.M. 2004. Murciélagos (Chiroptera-Mammalia) de la Mesopotamia argentina. In: Aceñolaza, F.G. (Coord.). Temas de biodiversidad del litoral fluvial argentine. Instituto Superior de Correlación Geológica. p. 369-378. (Miscelánea 12)

Barquez, R.M. 2006. Orden Chiroptera. In: Barquez, R.M.; Díaz, M.M. \& 0jeda, R.A. (Eds.). Mamíferos de Argentina. Sistemática y distribución. Mendoza, Sociedad Argentina para el Estudio de los Mamíferos (SAREM). p. 56-86.

Barquez, R.M. \& Díaz, M.M. 2009. Los Murciélagos de Argentina, Clave de Identificación. Tucumán, PCMA Programa de Conservación de los Murciélagos de Argentina. 84 p. (Publicación Especial № 1).

Barquez, R.M.; Claps, G.L. \& Autino, A.G. 1991. Nuevos registros de ectoparásitos de murciélagos en el noroeste argentino. Revista de la Sociedad Entomológica Argentina, 49(1-4): 78; 102.

Barquez, R.M.; Miotti, M.D.; Idoeta, F.M. \& Díaz, M.M. 2017. Two new species of Myotis (Chiroptera: Vespertilionidae) for Argentina. Papéis Avulsos de Zoologia, 57(22): 287-294.

Bilenca, D. \& Miñarro, F. 2004. Identificación de las áreas Valiosas de Pastizal (AVPS) en las Pampas y Campos de Argentina, Uruguay y Sur de Brasil. Buenos Aires, Fundación Vida Silvestre Argentina. 353p.

Brown, A.; Martínez-Ortiz, U.; Acerbi, M. \& Corcuera, J. 2006. La situación ambiental Argentina 2005. Buenos Aires, Fundación Vida Silvestre Argentina. 587p.

Burkart, R.; Bárbaro, N.; Sánchez, R. \& Gómez, D. 1999. Eco-regiones de la Argentina. Buenos Aires, Administración de Parques Nacionales, Programa de Desarrollo Institucional. 42p.

Claps, G.L. \& Autino, A.G. 2012. Myodopsylla wolffsohni wolffsohni (Siphonaptera, Ischnopsyllidae) sobre murciélagos de la Argentina y Uruguay. Revista de la Sociedad Entomológica Argentina, 71(1-2):155-157.

Claps, G.L.; Autino, A.G. \& Barquez, R.M. 2000. Nuevos registros de Streblidae (Diptera) para la Argentina. Acta Zoológica Mexicana (nueva serie), 80: 241-243. 
Claps, G.L.; Autino, A.G.; Merino, M.L. \& Abba, A.M. 2004. Nuevas citas de insectos ectoparásitos de murciélagos para las provincias de Buenos Aires y Corrientes, Argentina. Physis, seccion c, 59: 53-56.

Coquillett, D.W. 1899. New genera and species of Nycteribiidae and Streblidae. Canadian Entomologist, 31(11): 333-336.

Coquillett, D.W. 1907. Notes and descriptions of Hippoboscidae and Streblidae. Entomological News, 18: 290-292.

Costa Lima, A. 1921. Sobre os Streblideos americanos (Diptera-Pupipara). Archivos da Scola Superior da Agricultura e Medicina Veterinaria, 5: 17-33.

Di Benedetto, I.M.D.; Autino, A.G.; González, C.A. \& Argoitia, M.A. 2017. Propicimex tucmatiani (Wygodzinsky, 1951) (Hemiptera: Cimicidae: (imicinae) ectoparásitos de murciélagos, nuevo para la provincia de Corrientes, Argentina. Check-List, 13(5): 1-4.

Di Giacomo, A. \& Krapovickas, S. 2005. Conserving the grassland Important Bird Areas (IBAs) of Southern South America: Argentina, Uruguay, Paraguay, and Brazil. USDA Forest Service General Technical Report, PSW-GTR-191, 1-7.

Díaz, M.M.; Aguirre, L.F. \& Barquez, R.M. 2011. Clave de identificación de los murciélagos del cono sur de Sudamérica - Key of the bats of the Southern Cone of South America. PCMA (Programa de Conservación de los Murciélagos de Argentina) - PCMB (Programa de Conservación de los Murciélagos de Bolivia). Bolivia, Centro de Estudios de Biología Teórica y Aplicada. 157p.

Dick, C.W. 2013. Review of the bat flies of Honduras, Central America (Diptera: Streblidae). Journal of Parasitology Research, I (Article ID 437696): 1-17. DOI

Dick, C.W. \& Bindokas, M. 2007. Checklist of World Polyctenidae (Hemiptera: Cimicoidea). https://www.researchgate.net/publication/322725590.

Dick, C.W. \& Graciolli, G. 2018. Checklist of world Streblidae (Diptera: Hippoboscoidea). Center for Integrative Research, The Field Museum of Natural History, Chicago, III. Available: https://www.researchgate.net/ publication/322578987 Checklist of World Streblidae Diptera Hippoboscoidea. Access: 11/06/2020.

Dick, C.W.; Gettinger, D. \& Gardner, S.L. 2007. Bolivian ectoparasites: a survey of Bats (Mammalia Chiroptera). Comparative Parasitology, 74(2): 372-377.

Ferris, G.F. \& Usinger, R.L. 1939. The family Polyctenidae (Hemiptera: Heteroptera). Microentomology, 4(1): 1-50.

García, M. 1959. Diptera Pupipara. In: Jornadas Entomoepidemiológicas Argentinas, 1a. Buenos Aires, Prensa Medica Argentina. v. 2, p. 579-580.

García, M. \& Casal, 0.H. 1965. Revisión de las especies del genero Euctenodes Waterhouse, 1879 (Diptera, Acalypterae, Streblidae). Notas Biológicas de la Facultad de Ciencias Exactas, Fisicas y Naturales, Série Zoologia, Corrientes, 5: 3-23.

Graciolli, G. 2004. Nycteribiidae (Diptera, Hippoboscoidea) no Sul do Brasil. Revista Brasileira de Zoologia, 21(4): 971-985.

Graciolli, G. \& Carvalho, C.J.B. de 2001. Moscas ectoparasitas (Diptera, Hippoboscoidea) de morcegos (Mammalia, Chiroptera) do Estado do Paraná. II. Streblidae. Chave pictórica para generos e especies. Revista Brasileira de Zoologia, 18(3): 907-960.

Guerrero, R. 1995. Catálogo de los Streblidae (Diptera: Pupipara) parásitos de murciélagos (Mammalia: Chiroptera) del Nuevo Mundo. V. Trichobiinae con alas reducidas 0 ausentes y misceláneos. Boletín de Entomología Venezolana Nueva Serie, 10(2): 135-160.

Guerrero, R. 1996. Catálogo de los Streblidae (Diptera: Pupipara) parásitos de murciélagos (Mammalia: Chiroptera) del Nuevo Mundo. VI. Streblinae. Acta Biológica Venezuélica, 16: 1-25.
Guimarães, L.R. 1946. Revisão das especies sulamericanas do genero Basilia (Diptera: Nycteribiidae). Arquivos de Zoologia do Estado de São Paulo, 5: 1-87.

Guimarães, L.R. \& D'Andretta, M.A. 1956. Sinopse dos Nycteribiidae (Diptera do Novo Mundo). Arquivos de Zoologia do Estado de São Paulo, 10(1): 1-184.

Idoeta, F.M. 2017. Murciélagos de los "campos y malezales" de Argentina: aspectos taxonómicos, corológicos y ecológicos. (Tesis Doctoral no publicada). La Plata, Buenos Aires, Argentina.

Jordan, K. 1922. The American Polyctenidae. Ectoparasites, 1: 204-215.

Lareschi, M.; Sanchez, J. \& Autino, A.G. 2016. A review of the fleas (Insecta: Siphonaptera) from Argentina. Zootaxa, 4103(3): 239-258.

Martínez-Crovetto, R. 1963. Esquema fitogeográfico de la provincia de Misiones. Bonplandia, 1(3): 171-223.

Matteucci, S.D. 2012. Ecorregión de Campos y Malezales. In: Morello, J.; Matteucci, S.D.; Rodriguez, A. \& Silva, M. (Eds.). Ecorregiones y complejos ecosistémicos Argentinos. Buenos Aires, Orientación Gráfica Editora S.R.L. p. 247-263.

Miranda Ribeiro, A. 1907. Algunos dípteros interessantes. Archivos do Museu Nacional de Rio de Janeiro, 14: 231-239.

Moratelli, R.; Peracchi, A.L.; Días, D. \& De Oliveira, J.A. 2011. Geographic Variation in South American population of Myotis nigricans (Schinz, 1821) (Chiroptera, Vespertilionidae), with the description of two new species. Mammalian Biology, 76: 592-607.

Oscherov, E.B.; Chatellanaz, M.L. \& Milano, A.M.F. 2006. Basilia carteri (Diptera: Nycteribiidae) en murciélagos de la Reserva provincial Iberá (Corrientes, Argentina). FACENA, 22: 3-6.

Oscherov, E.B.; Idoeta, F.M. \& Milano, A.M.F. 2012. Nuevos registros de ectoparasitos (Insecta: Diptera) de murciélagos (Chiroptera) del nordeste argentino. FACENA, 28: 63-68.

Ronderos, R.A. 1962a. Nuevos aportes para el conocimiento de los Polyctenidae Americanos (Hemiptera). Anales del Instituto Nacional de Microbiologia, 1: 67-76.

Ronderos, R.A. 1962b. Polyctenidae Americanos. II. (Hemiptera). Acta Zoologica Lilloana, 18: 259-262.

Scott, H. 1936. Descriptions and records of Nycteribiidae (Diptera: Pupipara), with a discussion of the genus Basilia. Zoological Journal of the Linnean Society, 39(267): 479-505.

Scott, H. 1940. Nycteribiidae from Southern Brazil (Diptera). Proceedings of the Entomological Society of London, 9(4): 57-61.

Séguy, E. 1926. Diptères exotiques peu connus. In:EncyclopédieEntomologique Ser. B II, Diptera. Paris. v. 3, p. 192-196.

Theodor, 0. 1967. An illustrated catalogue of the Rothschild collection of Nycteribiidae (Diptera) in the British Museum (Natural History). The British Museum (Natural History), London, 498 pp.

Ueshima, N. 1972. New World Polyctenidae (Hemiptera), with special reference to Venezuelan species. Brigham Young of University Sciences Bulletin, Biological Series, 17: 13-21.

Wenzel, R.L. 1976. The Streblid batflies of Venezuela (Diptera: Streblidae). Brigham Young of University Sciences Bulletin, Biological Series, 20(4): 1-177.

Wenzel, R.L.; Tipton, V.J. \& Kiewlicz, A. 1966. Ectoparasites of Panama. In: Wenzel, R.L. \& Tipton, V.J. (Eds.). The streblid batflies of Panama (Diptera: Streblidae). (hicago, Field Museum of Natural History, p. 405-675. 